\title{
Can Hinokitiol Kill Cancer Cells? Alternative Therapeutic Anticancer Agent via Autophagy and Apoptosis
}

\author{
Tae Bok Lee ${ }^{1,2}$, Jin Hyun Jun 2,3,4 $^{2}$ \\ ${ }^{1}$ Confocal Core Facility, Center for Medical Innovation, Seoul National University Hospital, Seoul, Korea \\ ${ }^{2}$ Department of Senior Healthcare, BK21 Plus Program, Graduate School of Eulji University, Seongnam, Korea \\ ${ }^{3}$ Department of Biomedical Laboratory Science, Eulji University, Seongnam, Korea \\ ${ }^{4}$ Eulji Medi-Bio Research Institute (EMBRI), Eulji University, Daejeon, Korea
}

\section{Hinokitiol에 의해 유도된 Autophagy 및 Apoptosis에 의한 대체 항암요법 연구}

\author{
이태복 ${ }^{1,2}$, 전진현 $2,3,4$ \\ ${ }^{1}$ 서울대학교병원 의학연구혁신센터 공초점현미경실, ${ }^{2}$ 을지대학교 대학원 BK21플러스 시니어헬스케어학과, ${ }^{3}$ 을지대학교 임상병리학과, \\ ${ }^{4}$ 을지대학교 을지의생명과학연구소
}

\section{ARTICLE INFO}

Received May 10, 2019

Revised May 28, 2019

Accepted May 29, 2019

\begin{abstract}
Cancer is genetically, metabolically and infectiously induced life threatening disorder showing aggressive growing pattern with invasive tendency. In order to prevent this global menace from jeopardizing human life, enormous studies on carcinogenesis and treatment for chemotherapy resistance have been intensively researched. Hinokitiol ( $\beta$-thujaplicin) extracted from heart wood of cupressaceous is a well-known bioactive compound demonstrating anti-inflammation, anti-bacteria and anti-cancer effects on several cancer types via apoptosis and autophagy. This study proposed that hinokitiol activates transcription factor EB (TFEB) nuclear translocation for autophagy and lysosomal biogenesis regardless of nutrient condition in cancer cells. Mitophagy and $\beta$-catenin translocation into the nucleus under treatment of hinokitiol on non-small cell lung cancer (NSCLC) cells and HeLa cells were investigated. Hinokitiol exerted cytotoxicity on HeLa and HCC827 cells; moreover, artificially induced autophagy by overexpression of TFEB granted imperfect sustainability onto HeLa cells. Taken together, hinokitiol is the prominent autophagy inducer and activator of TFEB nuclear translocation. Alternative cancer therapy via autophagy is pros and cons since the autophagy in cancer cells is related to prevention and survival mechanism depending on nutrition. To avoid paradox of autophagy in cancer therapy, fine-tuned regulation and application of hinokitiol in due course for successful suppressing cancer cells are recommended.
\end{abstract}

Copyright ${ }^{\odot} 2019$ The Korean Society for Clinical Laboratory Science. All rights reserved.

\section{INTRODUCTION}

Hinokitiol ( $\beta$-thujaplicin) is a natural bioactive substance found in the wood of cupressaceous used for antimicrobial

* Corresponding author: Jin Hyun Jun

Department of Biomedical Laboratory Science, Eulji University, 553 Sanseong-daero, Sujeong-gu, Seongnam 13135, Korea

E-mail: junjh55@hanmail.net

* ORCID: https://orcid.org/0000-0001-9898-4471 agent, shows antitumor effects via autophagic signaling pathway [1]. The chemical structure of $\beta$-thujaplicin (2-hydroxy-4-isopropyl-2,4,6-cycloheptatrien-1-one) which contains tropone structure (2,4,6-cycloheptatrien1 -one): seven-membered aromatic ring, is also found in several other phytochemicals with wide spectrum of biological effects and troponoids are naturally synthesized by plants to protect them from bacteria as a defense 
mechanism [2]. Autophagy is a physiological self-digestive process that has been evolutionarily conserved for cells to balance energy sources under nutrient deprivation condition or to adapt to the stress conditions in cells [3]. Cells utilize long-lived proteins and destroyed unnecessary cellular organelles for energy sources or materials for cell formation under nutrient deprivation via autophagy [4]. During autophagy in mammalian cells, cytoplasmic constituents sequestrated by autophagosome are digested by lysosomal enzymes via lysosome-autophagosome fusion called autolysosome [5]. Initially, the autophagy was regarded as tumor suppression mechanism in that the deleted pattern of autophagy related genes: ATG6 and BECN1, are often observed in 70\% of human prostate, breast and ovarian cancers [6]. In the previous studies, the level of autophagy, during the early development stage of cancer, highly increased, whereas far reduced autophagy was shown in malignant stage of pancreatic cancer. This gives an idea that autophagy is in any way actively used during carcinogenesis and the decreased autophagy is essential to keep malignant stage of pancreatic cancer [7]. TFEB is regarded as a key regulator of autophagy due to its prominent capability to upregulate autophagy and lysosome related gene expression [8]. Under starvation condition, dephosphorylated TFEB migrates into the nucleus from cytoplasm in order to activate the target genes [9]. Recently, there has been a report that curcumin; hydrophobic polyphenol extracted from turmeric of the ginger family, directly interacts with TFEB for augmentation of TFEB nuclear translocation which ameliorates transcriptional activity of TFEB [10, 11]. More recent findings suggest that hinokitiol affects cancer cells in various ways depending on the concentration; treatment with non-toxic dose (1 $\sim \mu \mathrm{M})$ of hinokitiol does not exert severe cytotoxicity to normal cells but suppression of migration ability of human lung adenocarcinoma cells [12]. Hinokitiol is also related to the suppression of cancer stemness and glioma oncogenicity by downregulation of Nrf2 expression; on the other hand, melanoma is notably inhibited by hinokitiol via increased activity of antioxidant enzymes catalase (AEC) and superoxide dismutase (SOD) as well as downregulation of proteolytic enzymes; matrix metalloproteinase (MMP-2 and -9) [13, 14]. Moreover, the gefitinib-resistant lung adenocarcinoma cells and its proliferation are suppressed and negatively regulated by hinokitiol via three different pathways: inhibition of epidermal growth factor receptor/extracellular signaling regulated kinase (EGFR/ERK) signaling pathway; senescence via s arrest by DNA damage; and autophagy [15]. However, there have been rarely introduced of anticancer effect of hinokitiol against HeLa and HCC827 cells compared to the previous reports on curcumin and other cancer cells [16]. In this study, hinokitiol was used to see its anticancer effects on HeLa and HCC827 cells, and how effectively prevent cancer cell growth compared to normal cells. This study showed the first evidence of nuclear translocation of TFEB under treatment of hinokitiol in HeLa cells. Moreover, anticancer effects with considerable cytotoxicity of hinokitiol were shown in HeLa and HCC827 cells. Prevention of $\beta$-catenin nuclear localization was also observed with augmentation of mitochondrial fragmentation in NSCLC cells by treatment of hinokitiol.

\section{MATERIALS AND METHODS}

\section{Cell culture and transient transfection}

HeLa and fibroblast were cultured in Dulbecco's Modified Eagle's Medium (DMEM, Welgene, Korea) supplemented with 10\% Fetal Bovine Serum (FBS, Gibco, USA) and $1 \times$ Penicillin-Streptomycin antibiotics (Welgene). On the other hand, HCC827 cells were cultured in Roswell Park Memorial Institute 1640 medium (RPMI, Welgene) with same supplements. For transfection, HeLa and HEK293 cells were cultured at a confluence of $80 \%$ in a 12 well plate (Eppendorf, Germany). One microgram of DNA construct containing the TFEB sequence was incubated with $100 \mu \mathrm{L}$ of Opti-MEM and followed by mixing with 2 $\mu \mathrm{L}$ of TurboFect (Thermo, USA). The mixture was incubated at the room temperature for 20 minutes and carefully dropped into each well for the transfection. After the transfection, the well plate was incubated overnight at 
$37^{\circ} \mathrm{C}, 5 \% \mathrm{CO}_{2}$ in a humidified chamber and following day, cells were washed with DMEM or RPMI 1640 for 3 times and added with completed media.

\section{HeLa hTFEB-EGFP stable cell lines}

For the establishment of stable cell lines which continuously expresses TFEB-EGFP, TFEB coding sequence was amplified by PCR using the primers 5 'CCGAAGCTTATGCGTCACGCATAGGGTTG-3' and 5'GTCGGAATTCTCACAGCACATCGCCCTC-3' followed by subcloning into the EcoRI site of the pEGFP-C1 vector. HeLa cells were undergone of transfection with pEGFP-C1 (Cat \# 6084-1, GenBank, USA) which contains hTFEB using TurboFect (Thermo). On the following day, the transfected HeLa cells were cultured with selection media containing $400 \mu \mathrm{g} / \mathrm{mL}$ of G418 (Geneticin, Thermo) for 4 days, consecutively. The cell culture media were replaced every 4 days with higher concentration of G418 up to $1,000 \mu \mathrm{g} / \mathrm{mL}$ for 17 days. After which, each stably green fluorescence expressing colonies were isolated into FACS tube. The stably green fluorescence expressing cells were sorted using FACS ARIA2 (Becton, Dickinson and Company, USA) and data were analyzed by FACSDiva version 6.1.3 for better selection.

\section{Cell viability test}

For live/dead and viability/cytotoxicity test, calcein acetoxymethyl (AM) and ethidium homodimer kit (R37601, ThermoFisher, USA) were used. Live cells were labeled in green and excited at $475 \mathrm{~nm}$; on the other hand, dead cells were labeled in red and excited at $550 \mathrm{~nm}$. Emission filter for green was 500 550 nm and 570 650 nm filter set was used for red. Objective lenses were $5 \mathrm{x}$ Air NA 0.16 for realistic plate images. Percent cytotoxicity was calculated based on the following equation;

$$
\begin{gathered}
\text { Cytotoxicity } \\
(\%)
\end{gathered}=\frac{\text { No. of dead cells (red) }}{\text { No. of live cells (green)+No. of dead }} \times 100
$$

\section{Preparation of hinokitiol and curcumin supplemented Media}

In order to prepare hinokitiol and curcumin supplemented media, $\beta$-thujaplicin (2-Hydroxy-4-isopropyl2,4,6-cycloheptatrien-1-one, hinokitiol) and curcumin ((E,E)-1,7-bis(4-Hydroxy-3-methoxyphenyl)-1,6-heptad iene-3,5-dione, Diferuloylmethane) were purchased from Sigma-Aldrich (USA). Each compound was dissolved in DMSO (Sigma-Aldrich) and diluted using RPMI1640 media at $1 \mathrm{mM}$ of final concentration for ready to use.

\section{Hanging drop cell culture for 3D spheroids}

HCC827 cells were cultured at a 90\% confluence and harvested with $0.05 \%$ trypsin-EDTA in a $15 \mathrm{~mL}$ conical tube for dilution and adjustment of cell number to 100 cells/ $\mu \mathrm{L}$. Around 1,000 cells per well with $70 \mu \mathrm{L}$ of growth media were seeded into the GravityTRAPTM ULA Plate (inSphrero, Switzerland) for 3D formation. To remove the air bubbles, the plate were centrifuged at 250 relative centrifugal force $(\mathrm{RCF})$ for 2 minutes. The plate was incubated at $37^{\circ} \mathrm{C}, 5 \% \mathrm{CO}_{2}$ for seven days consecutively. Media were gently exchanged every two days using a $20 \mu \mathrm{L}$ pipette for three times remaining $10 \mu \mathrm{L}$ of residue volume.

\section{Immunofluorescent staining}

HCC827 cells were seeded into the $35 \mathrm{~mm}$ confocal dish (Cat \# 100350, SPL) and after 24 hours incubation, cells were stimulated by conditioned media: $10 \mu \mathrm{M}$ of hinokitiol for 16 hours. For the immunofluorescent staining, Cells were rinsed twice with $1 \times$ Phosphate buffered saline (PBS) and fixed with $4 \%$ Paraformaldehyde for 30 minutes at room temperature. The fixed cells were permeabilized with $0.2 \%$ triton $\mathrm{x}-100$ for 10 minutes and washed twice with $1 \times$ PBS. After which, cells were treated with the blocking buffer; $3 \%$ goat serum with $0.1 \%$ triton $\mathrm{x}-100$ in $1 \times$ PBS, for 30 minutes and rinsed 3 times with $1 \times$ PBS. Primary antibodies against $\beta$-catenin (rabbit anti- $\beta$-catenin, Ref \# 712700, Invitrogen, USA) were labelled on the shaker in the refrigerator at $4^{\circ} \mathrm{C}$ overnight. Secondary antibodies; Alexa 488 anti-rabbit IgG, were added into each well at 
room temperature for an hour followed by rinsing with $1 \times$ PBS. Nucleus was tagged with DAPI and DraQ5 (Cat \# 4084, CST, USA) and each sample was subjected to mounting for confocal microscopy.

\section{Immunocytochemistry for active caspase-3}

Cells were seeded on the slide glass and cultured for 24 hours. Four hours after exposure to curcumin or hinokitiol, cells were fixed using $4 \%$ paraformaldehyde and followed by rinsing with $1 \times$ PBS. Cell Conditioning 1 (CC1) standard (pH 8.4 buffer containing Tris/Borate/EDTA) was used for antigen retrieval. For automated immunohistochemistry staining, Discovery XT immunohistochemistry autostainer and Discovery ChromoMap DAB (3, 3'-Diaminobenzidine) kit (Ventana Medical Systems, Inc., Tucson, AZ, USA) were used. Slides were incubated with primary antibodies diluted as 1:500; cleaved caspase-3 (C8487, Sigma-Aldrich) for $32 \mathrm{~min}$ at $37^{\circ} \mathrm{C}$, and secondary antibody; Ultramap anti-rabbit HRP (Ventana, Roche, Switzerland) for $20 \mathrm{~min}$ at $37^{\circ} \mathrm{C}$. Slides were incubated in DAB with $\mathrm{H}_{2} \mathrm{O}_{2}$ substrate for $8 \mathrm{~min}$ at $37^{\circ} \mathrm{C}$ followed by hematoxylin and bluing reagent for counterstain at $37^{\circ} \mathrm{C}$. Reaction buffer (pH 7.6 Tris buffer) was used as washing solution in each step.

\section{Terminal deoxynucleotidyl transferase dUTP nick end labeling: TUNEL assay}

Slide glasses with $80 \%$ of cell confluency were subjected to exposure to given curcumin or hinokitiol agents for 4 hours. Cells were rinsed with PBS and endogenous peroxidase was quenched by 3.0\% hydrogen peroxide in PBS for $5 \mathrm{~min}$ at room temperature. Equilibration buffer was treated on the specimen followed by working strength terminal-deoxynucleotidyl-transferase (TdT) enzyme for 1 hour in the humid chamber $37^{\circ} \mathrm{C}$. After which, the specimen was subjected to working strength stop/wash buffer and anti-digoxignenin conjugate. Samples were washed thoroughly and gently tapped off to remove excess liquid and treated with peroxidase substrate for 5 min at room temperature. Counterstain was made using $0.5 \%(\mathrm{w}: \mathrm{v})$ methyl green and washed with $\mathrm{dH}_{2} \mathrm{O}$. All these
TUNEL stain kit (S7100) was purchased from Millipore (Germany).

\section{Live confocal microscopy and drug treatments}

All the confocal microscope images were acquired using a Leica TCS SP8 STED CW System and Leica DMI 6000 inverted fluorescent microscope. The molecules labelled in green fluorescence: EGFP and Alexa 488 dye, were respectively excited using Argon $488 \mathrm{~nm}$ laser with $10 \%$ of output and $20 \%$ of laser power. On the other hand, red fluorescence with Alexa 568, was excited using DSPP $561 \mathrm{~nm}$ laser with $5 \%$ of laser power. Photomultiplier (PMT) detector and Hybrid Detector (HyD, Hamamatsu) were used for detection of emission and scan speed was $400 \mathrm{~Hz}$ using $8 \times$ line average with 1 Airy unit pinhole setting. Emission spectral detection ranges were 500 $550 \mathrm{~nm}$ for green fluorescence and $580 \sim 650 \mathrm{~nm}$ for red fluorescence. EGFP-hTFEB transfected live stable cells were imaged in real time on the top-stage incubation system (Chamlide TCTM, LCI) which continuously keeps $37^{\circ} \mathrm{C}$ warm environment and provides $5 \% \mathrm{CO}_{2}$ gas. Pre-warmed conditioned media at $37^{\circ} \mathrm{C}$ were added into the confocal dish using the fluid injector on the stage of confocal microscope.

\section{Confocal image analysis}

Nuclear translocation of TFEB labelled in green fluorescence was analyzed using Leica LAS X quantify and analysis function. Intensity based mean value of green fluorescent signal representing hTFEB-EGFP, was automatically calculated with the equation that pixel sum intensity is divided by a region of interest (ROI) area pixel. The ROI size was fixed at $50 \mu \mathrm{m}$ and same ROI size was applied to measure green signals both in nucleus and cytosol. For molecular counting in $\beta$-catenin translocation and lysosomal puncta, confocal images were analyzed by IMARIS image analysis software V. 7.6.2 using add spots and section mode. Estimated diameter of molecules for $\beta$-catenin was determined in slice view as follows; the smallest green dot in the images was approximately 100 $\mathrm{nm}$. Lysosomal puncta were measured in the same way 
around $1.2 \mu \mathrm{m}$ up to $2 \mu \mathrm{m}$. Mitochondria tube length and area were measured with angiogenesis function, MetaMorph (Molecular Devices, USA).

\section{High content screening (HCS) analysis}

Cells were seeded into 96 well plate (CellCarrier 96 Ultra, PerkinElmer, USA) for image acquiring and cell HCS analysis: cytotoxicity, mobility and cell tracking, using Operetta CLS, PerkinElmer. Cells were imaged using z-stack function to find best focus area and well based images were analyzed and showed as heat maps and line graphs combined with merged realistic plate images for cell viability against hinokitiol. Cell count and tracking based on plate images were analyzed using digital phase

A)
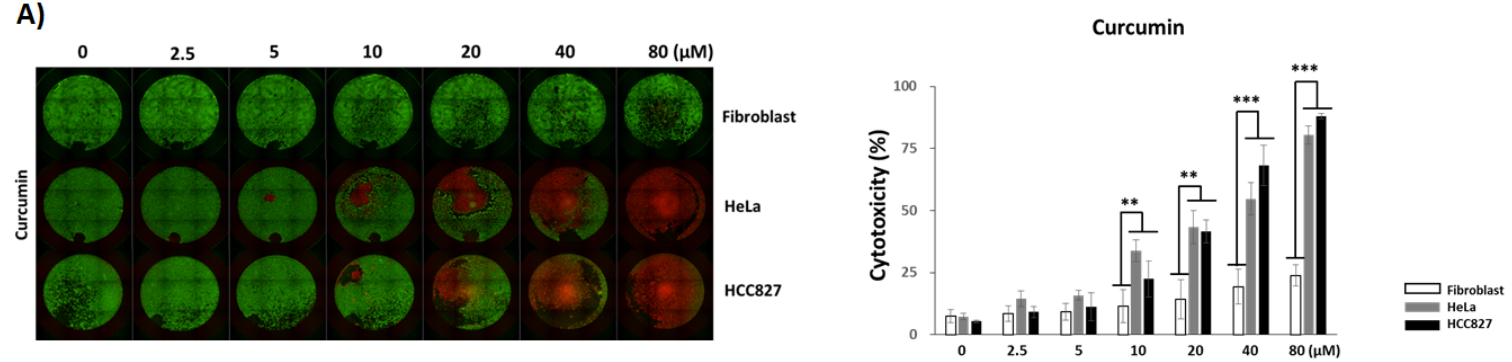

B)
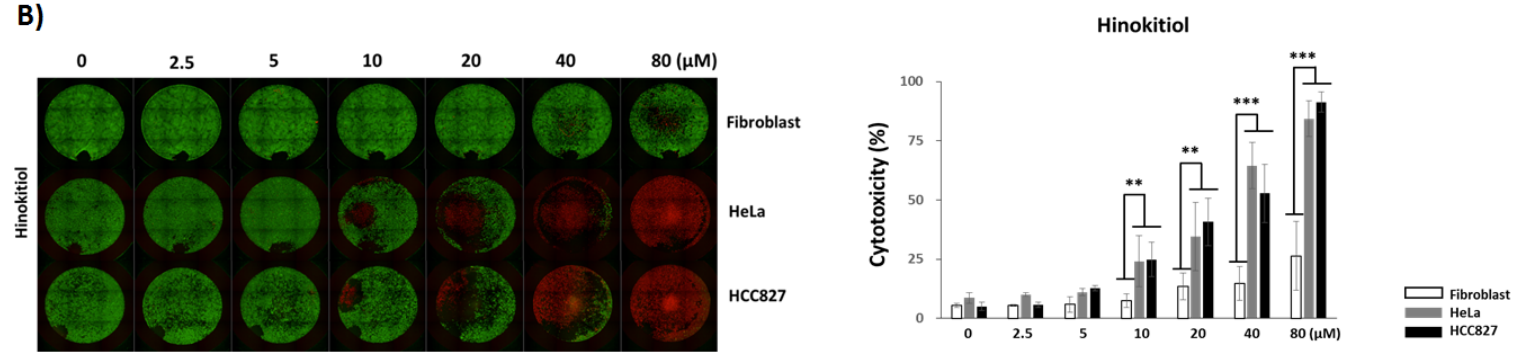

C)

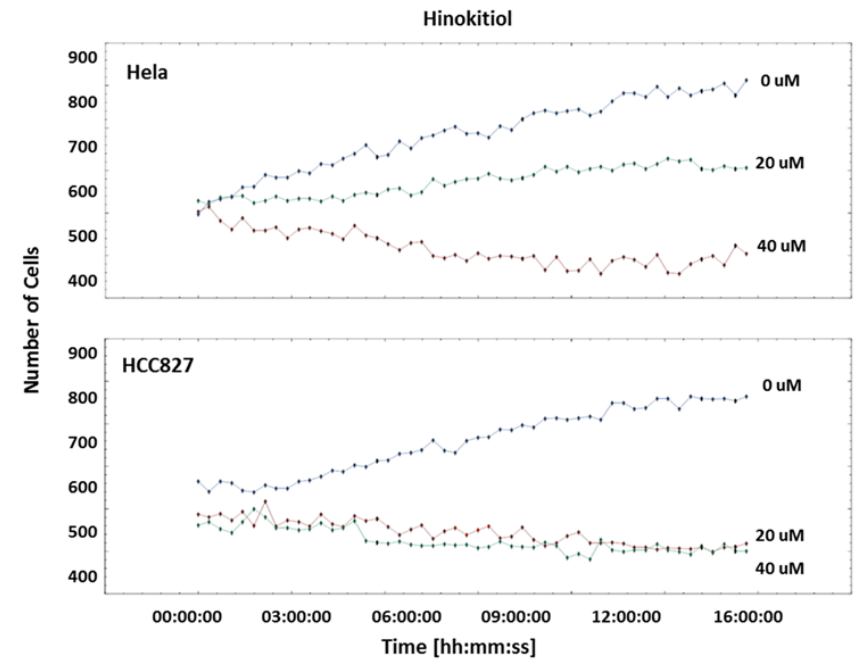

Figure 1. Effects of hinokitiol and curcumin on cell viability of normal and cancer cells. Fibroblast, HeLa and HCC827 cells were treated with hinokitiol and curcumin depending on the indicated concentration for 16 hours. (A and B) A realistic plate images of cell viability test on each cell line under treatment of curcumin or hinokitiol. Live cells were labeled with calcein AM colored green and dead cells were colored red with ethidium homodimer-1. Cytotoxicity was calculated based on the ratio analysis of live and dead cells. (C) Cell proliferation analysis after treatment of hinokitiol with indicated concentration. Data are expressed as the mean \pm SD of hexaplicate determinations. ${ }^{\star \star} P<0.01 ;{ }^{\star \star \star} P<0.001$. Cell counting was repeated more than three times. 
contrast (DPC) and DAPI (NucBlue_Live Cell Stain, \#R37605, Molecular Probes, USA).

\section{RESULTS}

1. Effects of curcumin and hinokitiol on cell viabilities of cancer cell lines

The cell viability was examined using three different cell lines: Fibroblast, HeLa and HCC827, against curcumin and hinokitiol respectively. As shown in Figure 1A, curcumin gradually exerted cytotoxicity against depicted three cancer cell lines: HeLa $\left(\mathrm{IC}_{50}=41.52 \pm 3.96 \mu \mathrm{M}\right)$ and HCC827 $\left(\mathrm{IC}_{50}=35.55 \pm 4.23 \mu \mathrm{M}\right)$. Similarly, hinokitol also showed cytotoxicity on those cancer cell lines: HeLa ( $\mathrm{IC}_{50}=38.58 \pm$ $6.72 \mu \mathrm{M})$ and $\mathrm{HCC} 827\left(\mathrm{IC}_{50}=37.63 \pm 5.41 \mu \mathrm{M}\right)$ (Figure 1B). Interestingly, cancer cell proliferation inhibitory activities were also observed as hinokitiol diluted solution was added into culture media with different concentration: 0 , 20 and $40 \mu \mathrm{M}$ on HeLa and HCC827 cells during sixteen hours live imaging observation using high content screening method (Figure 1C). These data indicates that hinokitiol is alternatively applicable on the mentioned cancer cells in lieu of curcumin for cancer treatment and prevention.

\section{Apoptosis induced by curcumin and hinokitiol}

The caspase- 3 activity was examined to determine how curcumin and hinokitiol increase cytotoxicity in NSCLC cells. Active caspase-3 positive cells were significantly increased in the curcumin or hinokitiol treated groups compared to the control in HCC827 cells. Additional TUNEL stain result was very much consistent with active caspase-3 analysis wherein TUNEL positive cells were slightly increased in curcumin or hinokitiol treated groups compared to the control (Figure 2). These data implied that increased cytotoxicity and apoptotic cell death was caused by curcumin and hinokitiol. The effect of apoptotic death, however, cannot clearly explain the massive cancer cell death which was shown in figure 1 and that casted an inquiry that another mechanism: autophagic death, is possibly related to the cancer cell death by curcumin and hinokitiol.

\section{TFEB nuclear translocation and increased lysosomal puncta triggered by hinokitiol treatment in HeLa cells}

The hypothesis postulated in this section is hinokitiol activates autophagy under nutrient rich condition via TFEB dephosphorylation and its nuclear translocation possibly leads to the stimulation of lysosome and
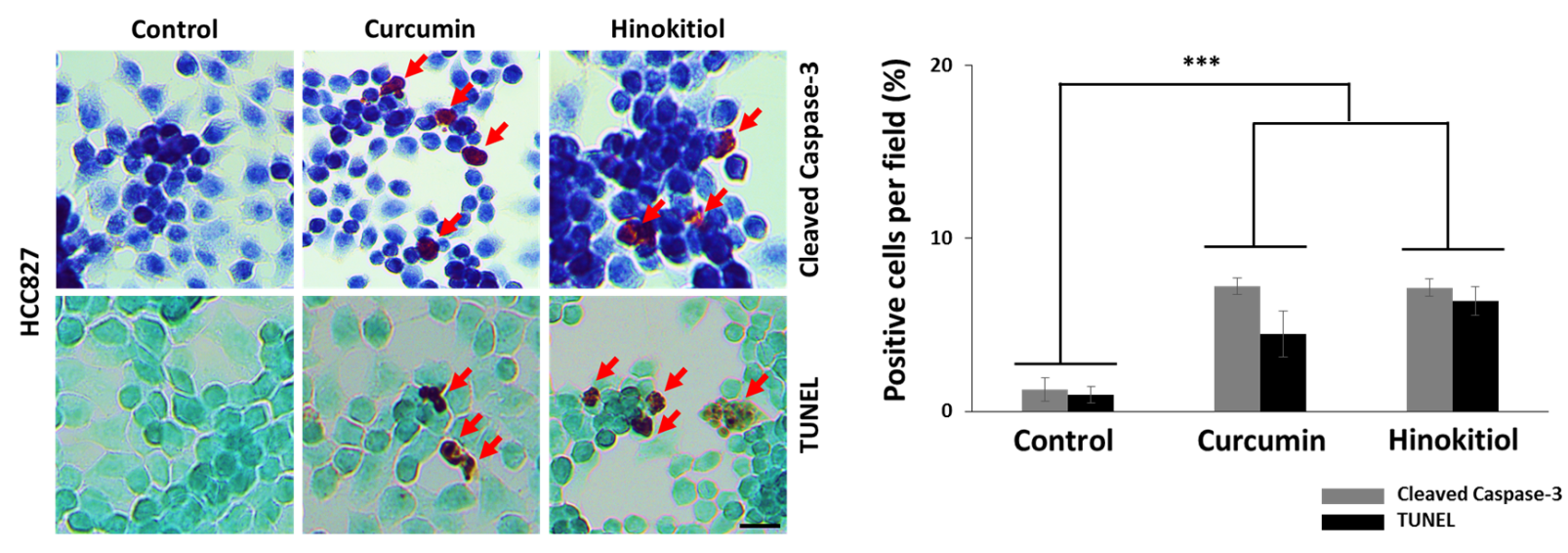

Figure 2. Immunocytochemistry of cleaved caspase-3 and TUNEL stain in HCC827 cells. Wide-field microscope images of HCC827 cells. Cleaved caspase- 3 and TUNEL staining were performed for visualization of apoptosis after 8 hours of treatment with $20 \mu \mathrm{M}$ of curcumin or hinokitiol. Cleaved caspase-3 and TUNEL positive cells were shown in brown color while cleaved caspase-3 and TUNEL negative cells were shown in blue and green, respectively (upper panel). Quantitative analysis with percentage of cleaved caspase-3 and TUNEL positive cells (lower panel). Data were expressed as the mean \pm SD of hexaplicate determinations. ${ }^{* \star} P<0.001$. Cell counting was repeated three times. Scale bars, $20 \mu \mathrm{m}$. 
autophagy related genes. To this end, GFP-TFEB construct were transfected into HeLa and HCC827 cells for single cell colony selection under G418 treatment followed by FACS sorting. Unlike the GFP-TFEB HeLa cells, GFP-TFEB HCC827 cells were not successfully established by commercially available transfection methods followed by colony selection and FACS sorting (Data not shown). As introduced in the previous studies, TFEB migrated into nucleus under nutrient deprivation condition in GFP-TFEB HeLa cells. Moreover, TFEB nuclear translocation was clearly observed by treatment of hinokitiol in line with the previously reported study of starvation (Figure 3A). Lysotracker; lysosome labelling dye for live imaging, has been used for detection of autophagy in the previous reports and in this study, the lysotracker was applied for monitoring TFEB and its downstream target gene expression: lysosome. To see whether hinokitiol activates lysosome expression, the TFEB stably expressed HeLa cells were used for evaluation of physical differences of lysosome before and after treatment of hinokitiol. As shown in Figure 3B, the number of lysosomal puncta over $1.2 \mu \mathrm{m}$ diameter were counted using Imaris V. 7.6.2,

A)
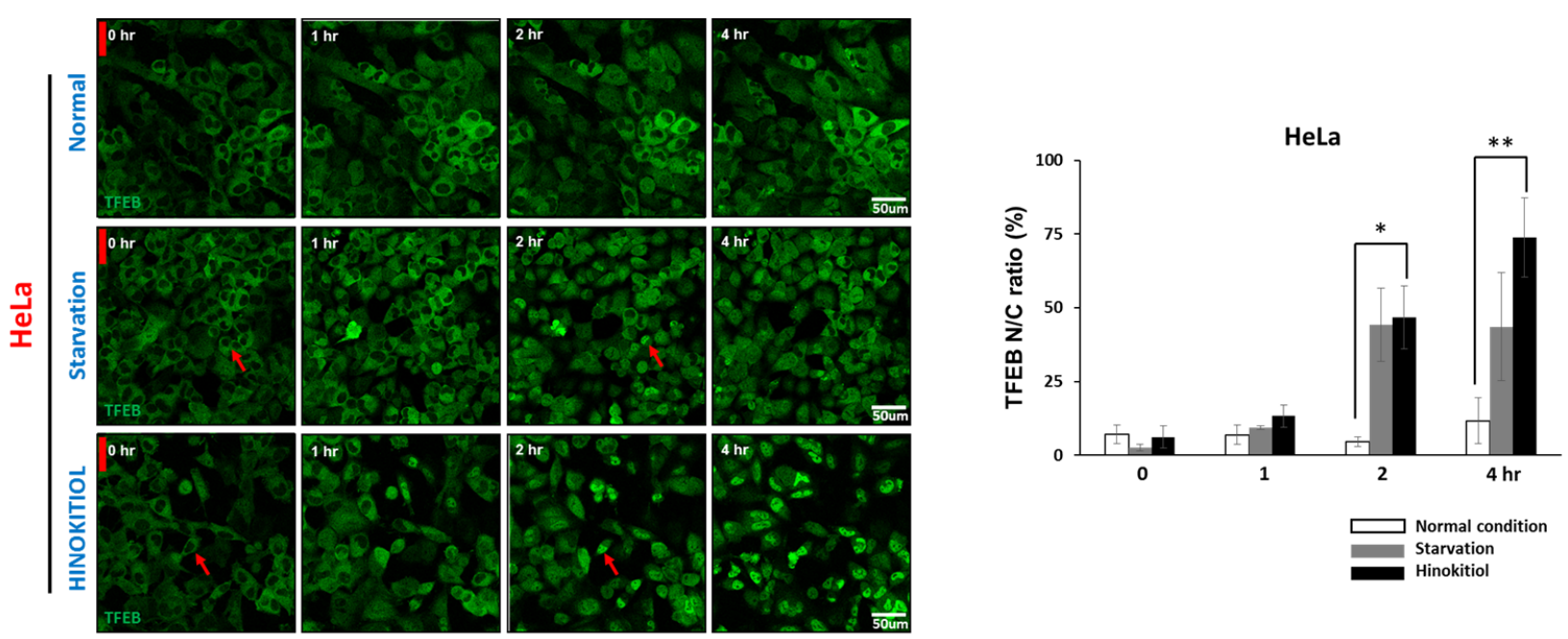

B)
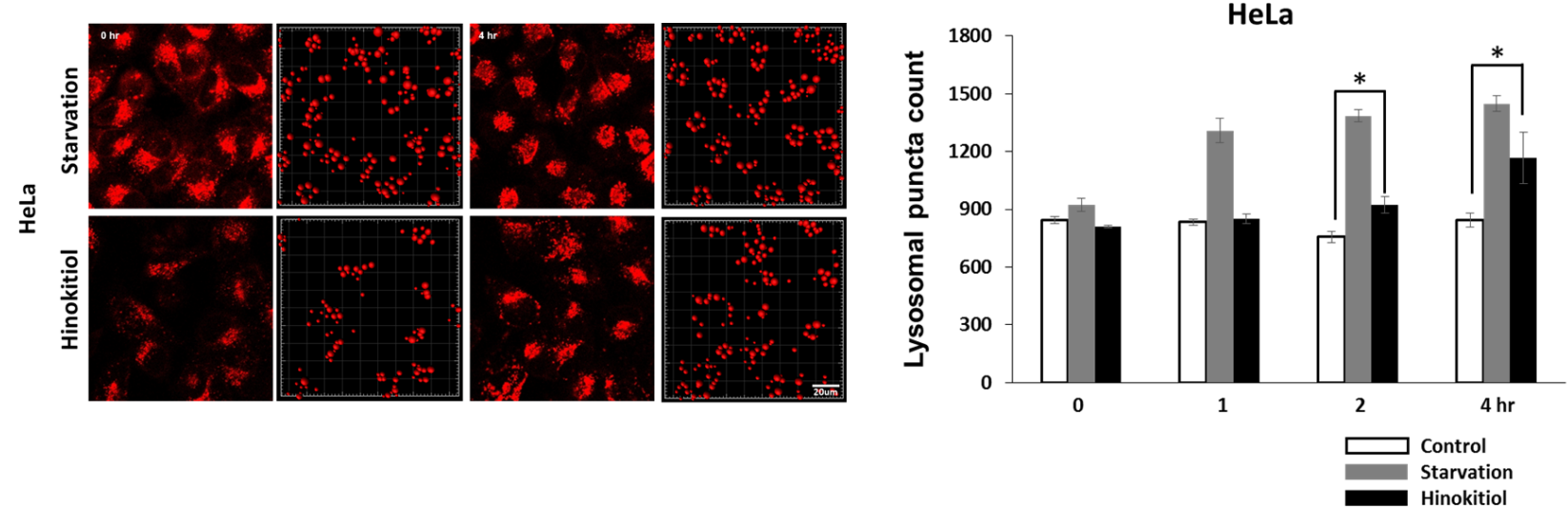

Figure 3. TFEB nuclear translocation and lysosomal puncta enlargement after treatment of hinokitiol and curcumin in HeLa cells. (A) Confocal live images and time dependent GFP N/C ratio analysis bar graphs in HeLa GFP-TFEB transfected stable cells after exposure to serum starvation or hinokitiol, respectively. Hinokitiol triggers GFP-TFEB nuclear translocation under nutrient rich condition in HeLa cells. (B) Enlarged lysosomal puncta after treatment of hinokitiol in HeLa cells. Lysotracker real-time observation in confocal microscope after treatment of hinokitiol and starvation compared to time point $0 \mathrm{hr}$ in HeLa cells. Images were taken at 0, 1, 2 and 4 hours after treatment of hinokitiol and starvation, respectively. 
Bitplane. In parallel with the starvation condition, the number of puncta were gradually increased after treatment of hinokitiol in HeLa cells. Importantly, the number of lysosome was increased and giant lysosomes were concomitantly observed under normal nutrient condition. These data suggest that hinokitiol promotes TFEB nuclear translocation with lysosomal activation regardless of the environment naturally controlled by the given nutrient.

\section{Impaired cell death caused by artificially induced autophagy in TFEB overexpressed cells and diminished cytotoxic effect of hinoktiol in HCC827 cells introduced by autophagy inhibitor}

The hypothesis was established to explore the relationship between autophagy and cancer cell death that increased TFEB in cancer cells and artificially upregulated autophagy by extrinsic stress will negatively react to cancer cell viability. In brief, additionally applied hinokitiol to the cancer cells subjected to autophagy upregulation by TFEB, will synergistically lower the cell viability due to the lost balance of autophagy for its sustainability. To this end, the experiment was designed to see whether TFEB induced autophagy can prolong the viability of cancer cells at the basal level and compare the anticancer effect between wildtype and the autophagy activated group under treatment of hinokitiol. Depending on the concentration of hinokitiol treated, it showed gradually increased cytotoxicity in the wildtype HeLa cells. On the other hand, artificially increased autophagy showed significantly dominant cytotoxicity at higher concentration of hinokitiol and even showed moderately augmented cytotoxicity in the basal level compared to the wild type (Figure 4A). As a result, TFEB transfection into HeLa cells demonstrated a significantly shortened IC50 (19.07 $\pm 7.14 \mu \mathrm{M}$, hinokitiol) with reduced cell viability compared to the previous experiment described in Figure 1. Of note, increased autophagy system in HeLa cells leaded to the lower cell viability compared to the wildtype HeLa cells without exposing to the anticancer agent. When the therapeutic agents were added into the HeLa cells where the additional autophagy was induced by TFEB overexpression, exaggerated cytotoxicity was observed in both experiments with hinokitiol. Another finding was that autophagy inhibition by pretreatment of chloroquine notably reduced the dead cells caused by hinokitiol treatment in HCC827 cells (Figure 4B). Taken together, the massive cell death by hinokitiol is related to the TFEB nuclear translocation and followed by continuous autophagy induction (Figure 4C).

\section{Increased mitophagy and interupted $\beta$-catenin nuclear translocation with lowered cell movement \\ by hinokitiol treatment in cancer cells}

Mitophagy is the degradation process of hyper fragmented mitochondria via autophagy in order to remove the damaged and defective mitochondria in cells. Functional damage, impaired mitochondrial dynamics and biogenetics caused by retention of anticancer agent in the mitochondria resulted in significant cell death with increased mitophagy. To see whether hinokitiol induces mitophagy in HCC827 cells, four hours after treatment of hinokitiol, HCC827 cells were labeled with mitotracker for mitochondria and lysotracker for lysosome. Co-localization of mitochondria and lysosome was considerably increased in HCC827 cells compared to mouse embryonic fibroblast (MEF) cells (Figure 5A). This gave the clear evidence that autophagic degradation is intermediated by hinokitiol through the hyper-segmentation of mitochondria and that is maybe related to the massive cell death in HCC827 under treatment of hinokitiol. Cell proliferation was intensively prohibited when hinokitiol was treated on HeLa and HCC827 cells (Figure 1C). Wnt signaling is the key component in caner biology due to its variety of target genes connected to the cell proliferation. To assess the localization of $\beta$-catenin which is the key component in the downstream of Wnt signaling transduction, immunofluorescent staining after exposure to DMSO as a control or hinokitiol, was implemented in order to calculate the molecular localization of $\beta$-catenin. Indeed, mitigated $\beta$-catenin nuclear localization was observed in the confocal microscope and molecular counting image 
A)
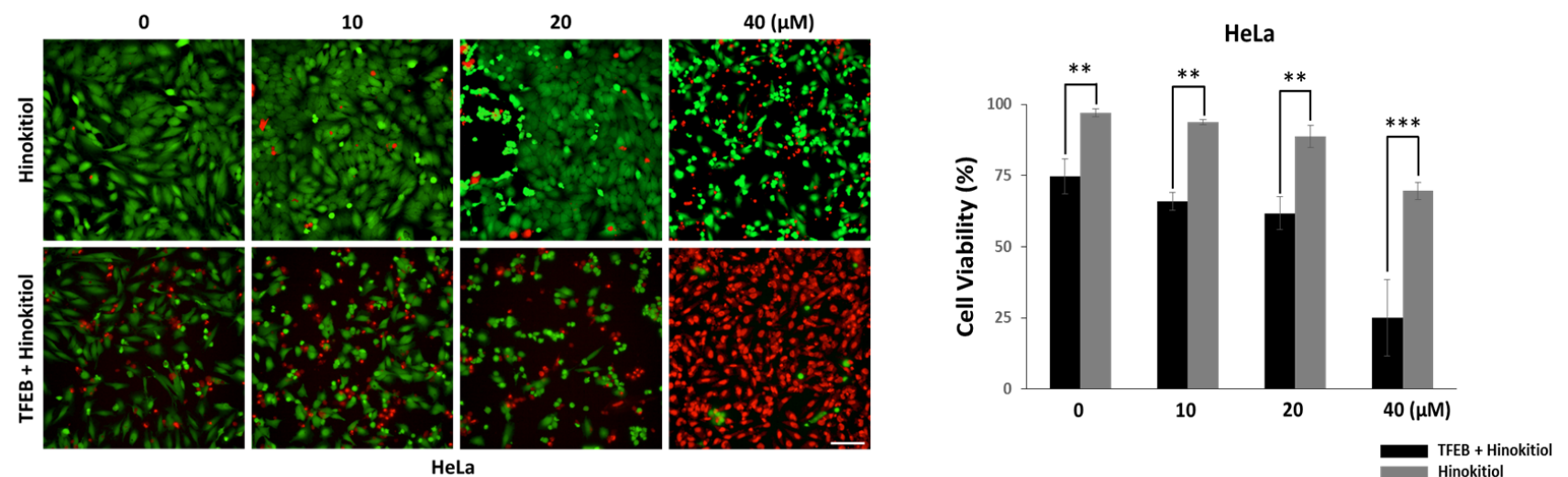

B)

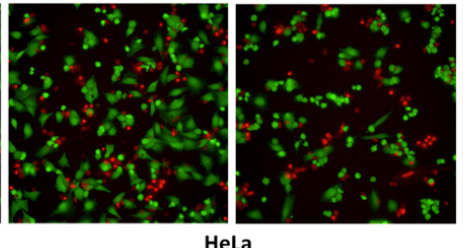

Hinokitiol
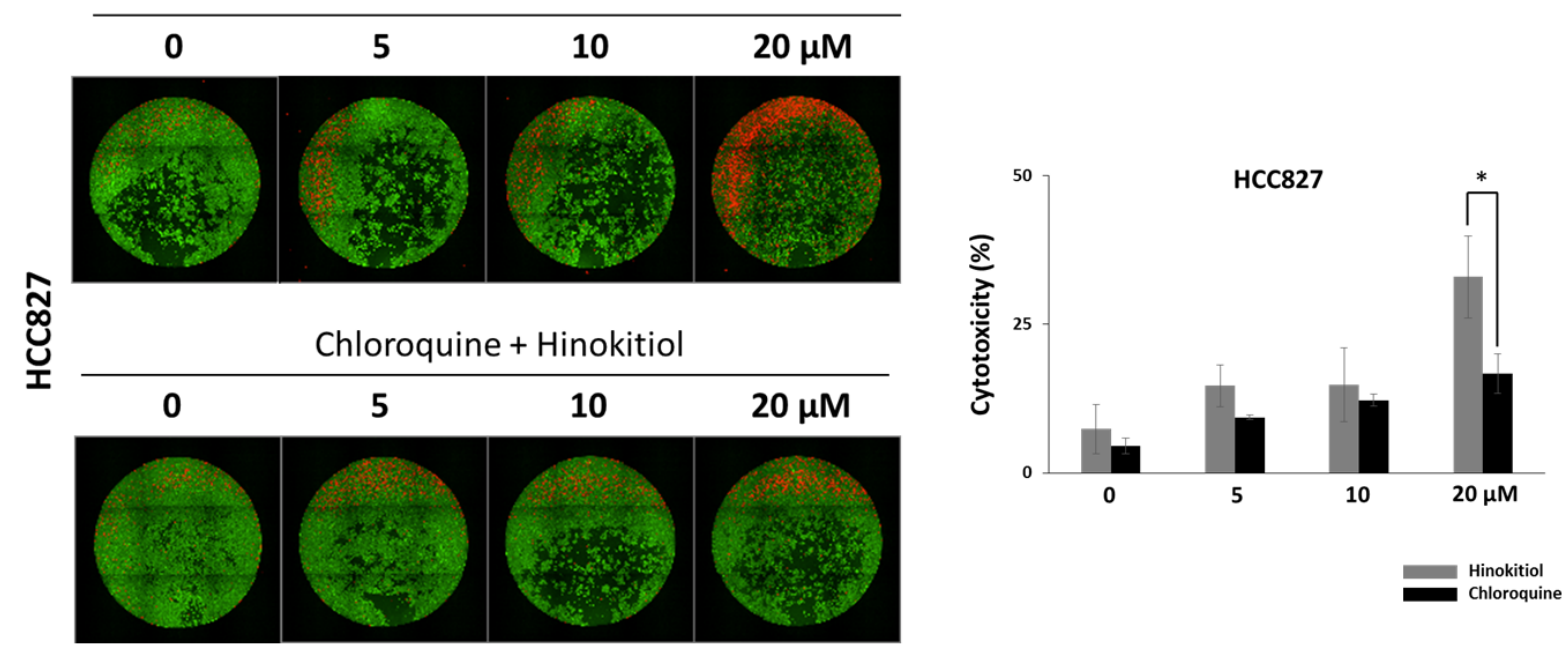

C)

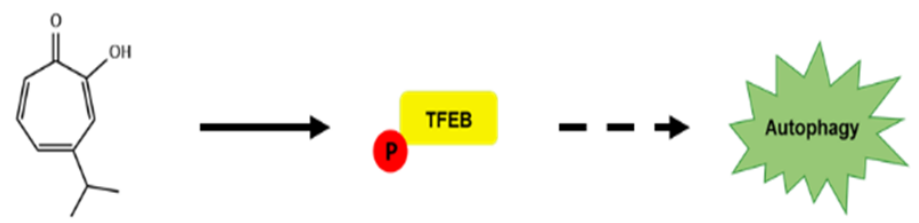

\section{Hinokitiol}

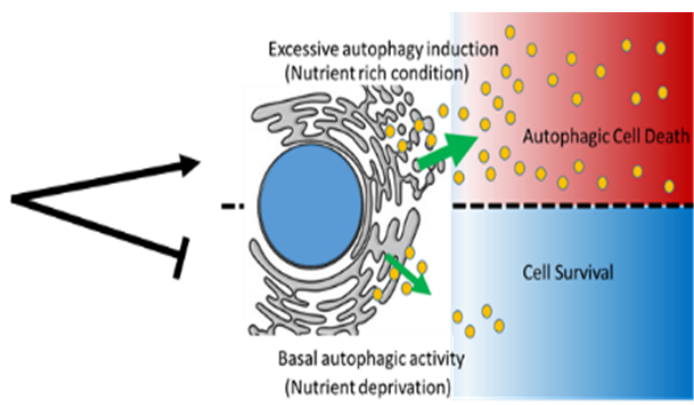

Figure 4. Impaired cell viability induced by TFEB and alleviated cytotoxic effect by pre-treatment of chloroquine in HCC827 cells. (A) Confocal images of live and dead cells after treatment of hinokitiol in both wild type HeLa cells and TFEB-HeLa cells. Image based quantification data analysis by MetaMorph image analysis software, Molecular Devices. (B) High content screening images of live and dead cells, after treatment of hinokitiol with indicated concentration; 0, 5, 10 and $20 \mu \mathrm{M}$ in both HCC827 cells and chloroquine, an autophagy inhibitor, pretreated HCC827 cells. Quantification of cytotoxicity with graph was produced by Harmony image analysis software, PerkinElmer. (C) Diagram expatiating the pathway where hinokitiol triggers massive cell death via TFEB activation. Data are expressed as the mean \pm SD of hexaplicate determinations. ${ }^{*} P<0.05 ;{ }^{*} P<0.01$ and ${ }^{*} * x<0.001$. Cell counting was repeated three times with similar results. Scale bar, $100 \mu \mathrm{m}$.

analyzed by Imaris software upon treatment of hinokitiol (Figure 5B). Beta-catenin nuclear localization was reduced in hinokitiol treated group compared to control group.
Intriguingly, the 2D migration of HCC827 cells were notably reduced by treatment of hinokitiol (Figure 5C). Cell mobility, measured by cell tracking method, gave the 
A)

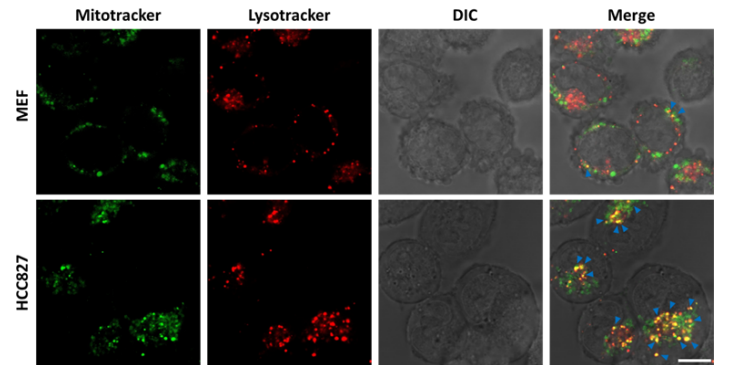

B)

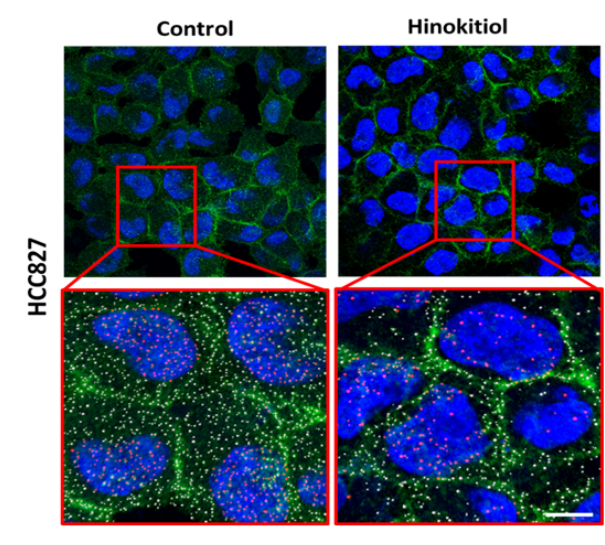

HCC827

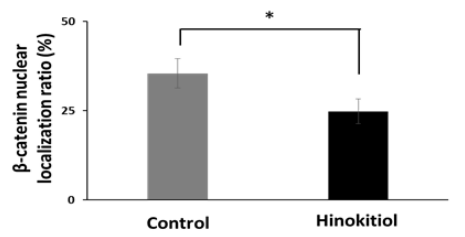

D)

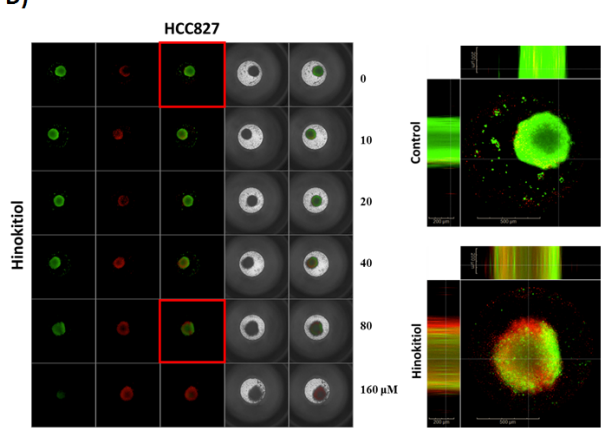

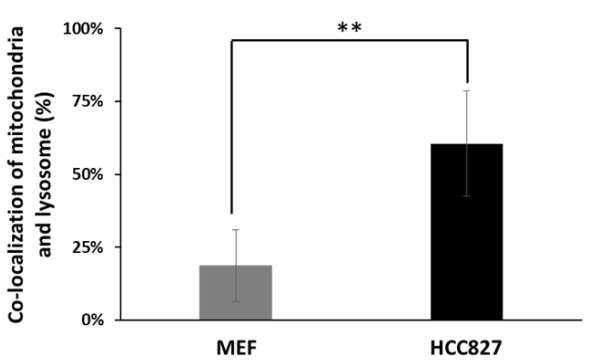

C)
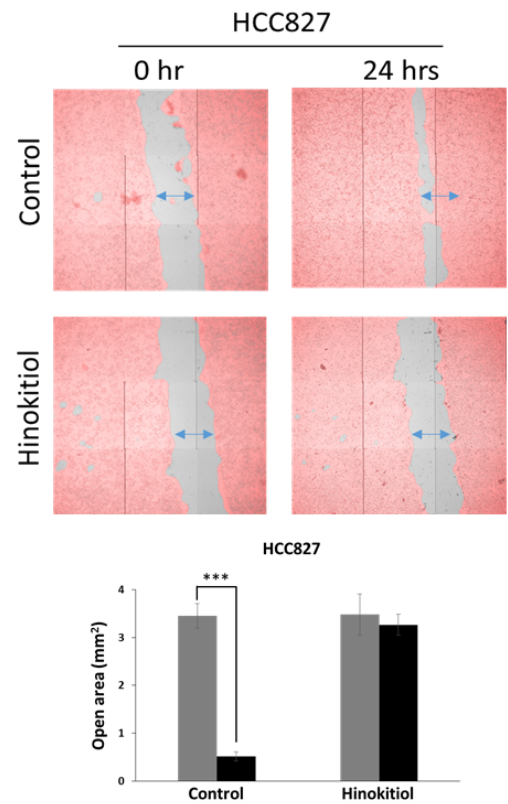

Figure 5. Co-localization of mitochondria and lysosome and $\beta$-catenin translocation with wound scratch migration after treatment of hinokitiol in HCC827 cells. HCC827 cells were treated with hinokitiol for 4 hours before labelling with mitotracker and lysotracker. (A) Mitochondria were shown in green and lysosome is shown in red. Merged images were shown with differential interference contrast (DIC) images. Co-localization between mitochondria (green) and lysosomes (red) were shown in yellow. Co-localization spots are indicated by arrows (blue). Quantification (\%) of co-localization by LAS-X image analysis software (Leica, Germany). (B) Confocal images of nucleus (DraQ5) and $\beta$-catenin (Alexa 488) under different conditions: DMSO and hinokitiol treatment in HCC827 cells. Image data were analyzed using add spots function in Imaris V. 7.6.2, Bitplane. Nuclear localized $\beta$-catenin ratio graph depending on different chemical treatment. (C) Wound scratch and cell migration analysis data. High content screening images were acquired using $10 \times / 0.3$ NA, Zeiss for 24 hours continuously, along the indicated condition: control and $10 \mu \mathrm{M}$ of hinokitiol. Scale bar, $10 \mu \mathrm{m}$. 
clue that cytotoxicity of anticancer agent not only affects the physiological changes: increased lysosome expression, introduction of giant lysosome, mitochondria segmentation and mitophagy, but also physical depravation like loss of movement. Significant cytotoxic effects shown in Figure 1 were remarkably demonstrated by hinokitiol in microtissues made of HCC827 cells depending on the concentration applied to the test (Figure 5D). Hinokitiol indeed lowered cancer cell proliferation through $\beta$-catenin signaling intervention and arrested cancer cell mobility depending on the concentration.

\section{DISCUSSION}

This study was started from the hypothesis that autophagy induced by hinokitiol is possibly related to the TFEB nuclear translocation regardless of nutrient manipulation and it is related to the cancer cell death. Autophagy is a well conserved self-degradative mechanism observed in eukaryote for cleaning long lived organelles, malfunctioning proteins and protecting cells from pathogen; besides recycling junk proteins for energy resource under nutrient deprivation [3, 5]. TFEB is a well-known transcription factor up-regulating autophagy and lysosomal biogenesis related genes during malnutrition period $[9,17]$. In the previous studies, hinokitol was described as an autophagy inducer and cancer inhibitor via HIF-1 or AKT/mTOR signaling pathway [18, 19]. To confirm whether TFEB nuclear translocation and autophagy activation is connected to the hinokitiol treatment on cancer cells, GFP-TFEB stable cell line was produced and relations between TFEB nuclear migration and lysosomal puncta were analyzed (Figure 3). In this experiments, curcumin was used as a positive control to hinokitiol due to its well-established anticancer effects as a natural derived bioactive compound in the previous report [20]. Indeed, hinokitiol satisfactorily showed anti-cancer effects on cervical and lung cancer cells along the increased concentration and exposure time (Figure 1) in consistent with earlier reports [12, 13]. Interestingly, there have been the reports that autophagy is used for cell survival not only during nutrient deprivation condition of normal cells but also cancer cells as a self-protecting mechanism for sustaining tumor growth against toxicity of cancer therapy [21]. On the other hand, there are many reports that autophagy can be used for cancer cell treatment [22]. TFEB overexpressed HeLa cells showed comparatively exacerbated cell viability with increased lysosomal puncta inferring active lysosome biogenesis and autolysosome formation (Figure 3 and 4). More interestingly, inhibition of autophagy with treatment of chloroquine showed reduced cytotoxicity in HCC827 cells compared to the hinokitiol treated group (Figure 4B). Mitochondria are highly dynamic organelles that can transform their morphology by fission or fusion in order to adjust to the different environments. These dynamics are also regulated by the BCL-2 protein and somehow affect the respiratory, ROS-generating, pro-inflammatory, and lethal signaling functions of mitochondria [23]. Mitochondria elongation which is the protective mechanism of cells when undergoing autophagy is the well-established theory [24, 25]. Hyperfusion and fragmentation of mitochondria is the reaction to the stress. Hyper fragmented mitochondria is tiny small and it can be the target of mitophagy [26]. Mitophagy is the degradation process of hyper fragmented mitochondria via autophagy in order to remove the damaged and defective mitochondria in cells [27]. Functional damage, impaired mitochondrial dynamics and biogenetics caused by retention of anticancer agent in the mitochondria resulted in significant cell death with increased mitophagy [28]. Autophagy is also relatively decreased by aging, and the expression of several key components: ATG5 and ATG7 are shown to be diminished among aging individuals [29]. Furthermore, the previous in vivo study revealed that artificially stimulated autophagy may increase the healthy lifespan in multiple experimental models including mice and primates [30]. In that regard, hinokitiol and its multiple application with other health supplements for senior healthcare as preventive and adjuvant remedies can be positively considered. The key component of Wnt signaling, $\beta$-catenin plays pivotal role in cell proliferation [31]. Failure in regulation of Wnt/ 
$\beta$-catenin signaling is widely linked to physical and physiological disorders: cancers, neurodegenerative diseases, birth defects and other diseases [32]. The level of $\beta$-catenin is regulated by destruction complex composed of Axin, GSK3 $\beta$ and adenomatous polyposis coli (APC) via phosphorylation, ubiquitination and proteosomal degradation in the cytoplasm during Wnt signal off state. Conversely, dephosphorylated $\beta$-catenin migrates into the nucleus and acts as a transcription factor for cell proliferation [33]. In the latest research, it has been reported that $\beta$-catenin and its relevant signaling pathway have important roles in proliferation of bladder cancer cells in three-dimensional organoid culture [34]. In line with the previous studies, nuclear localized $\beta$-catenin level were diminished after treatment of hinokitiol, meaning cancer cell proliferation is prohibited by hinokitiol. Moreover, cancer cell mobility was deterred by treatment of hinokitiol (Figure 5B and C). In short, increased autophagy system induced by the external therapeutic agent in HeLa and HCC827 cells seems deteriorate of survival rate and increase cytotoxicity. Directly or indirectly, all these events: upregulation of lysosome, giant lysosome, mitochondria fission, mitophagy, inhibited proliferation, slow-downed cell movement, inhibition of $\beta$-catenin translocation and massive cancer cell death, are seemingly connected. Slowing down cell mobility and stagnant proliferation rate under treatment of anti-cancer agent seems lead cancer cells to selfprotection state against extreme cytotoxic stress. However, exposure to the high dose of hinokitiol infallibly leads to the deterioration state in cancer cell viability. In the many studies, anticancer therapeutics using natural bioactive compounds are described as novel remedies replaceable to the present chemotherapy [35]. Controversially, autophagy has also been disputed as both tumor-suppressing mechanism and sustaining tumor growth in many studies [36]. In our previous study, co-treatment of hinokitiol and curcumin showed synergistic anticancer effect via apoptosis in NSCLC cells. However, the massive cell death caused by hinokitiol remained uncertain [37]. This study presented the first evidence that hinokitiol activate TFEB nuclear translocation and it upregulates autophagy and lysosomal biogenesis related gene expression leading to cancer cell death. Reportedly, anticancer effects of phytochemicals is largely divided into three major pathways: necrosis, apoptosis and autophagic death [38]. Artificially induced autophagy granted cancer cells poor viability under treatment of hinokitiol while hinokitiol exerted cytotoxicity with high dose overloading (Figure 4). Indeed, hinokitiol is the prominent autophagy inducer and it works with TFEB nuclear translocation. Downstream of Wht signaling was prohibited by hinokitiol (Figure 5) and it was known that autophagy inhibits Wnt signaling under starvation condition [39]. Wnt signaling is the prevalent theme in caner biology due to its variety of target genes connected to the cell proliferation [40]. Signaling relations among Hinokitiol, TFEB and Wht signaling under nutrient rich condition in order to prevent cancer is needed for further study. For successful application of hinokitiol as anticancer agent to suppress tumor cells, other autophagy related signaling pathways and in vivo experiments have to be precisely studied on dosedependent manner to avoid unexpected side effects. Hinokitiol can be an alternative and preventive anticancer agent for senior healthcare. The results of this study underline the application of hinokitiol for prevention and treatment of NSCLC cells. In particular, massive cancer cell death caused by hinokitiol is mediated by several innate mechanism of programmed cell death and organelles: lysosome and mitochondria. Hinokitiol differently showed cytotoxicity on normal cells with mild toxicity but severe cancer cell death in HeLa and HCC827 (Figure 1). In cancer, apoptotic cell death and autophagy are well balanced for cell survival. When this balance, however, is collapsed by hinokitiol showing autophagy stimulation, cancer cells appear to maneuver to autophagic death (Figure 4C). Hinokitiol, a natural product derived phytochemical, needs to be assessed as alternative adjuvant treatment for NSCLC cells due to its low cytotoxicity on normal cells. Based on this study, hinokitiol is the prominent candidate as a health supplement in alternative medicine and a therapeutic supplement for the preventive 
medicine in senior healthcare. In conclusion, this study presents that a potent anticancer agent: hinokitiol, exerts intensified cytotoxicity against cervical cancer and NSCLC cells. Induced cancer cell death is medicated by caspase-3 in apoptosis and subsequent enlarged lysosomes which are considered as sequestration of anticancer agents and that possibly leads to the lysosomal damage and increased autophagy followed by extreme cell death. The Development of alternative therapeutic strategy using hinokitiol, a natural product derivative, can be duly achieved by continuing efforts with further studies for establishing proper treatment mechanism in NSCLC with minimum cytotoxicity and maximized therapeutic effects.

\section{요 약}

암은 유전적, 대사질환적 그리고 감염성 질환 등에 의해 유발 되는 생명을 위협하는 심각한 질환으로서, 세포의 성장이 정상 적으로 통제되지 않으며, 공격적인 형태로 주변의 조직이나 장 기로 침범하는 경향을 보이는 생명을 심각하게 위협하는 질병 이다. 지난 수십 년 간, 인류의 건강을 위협하는 암을 정복하기 위한 지속적인 노력이 있었고, 암 신생 기전 및 항암제 연구가 항 암제 내성에 대한 연구와 함께 다양한 연구주제로 다루어져 왔 다. Hinokitiol ( $\beta$-thujaplicin)은 측백나무과 편백속에 속하는 나무에서 분비되는 terpenoid 물질로서, 항염증작용, 항균작용 및 몇몇 암세포 주에서 autophagy를 통한 항암효과가 있는 것 으로 잘 알려져 있다. 본 연구에서는, hinokitiol이 세포 영양상 태의 변화유무에 관계없이, transcription factor EB (TFEB)의 핵으로의 이동을 촉진한다는 것을 확인하였다. TFEB의 핵으로 의 이동은 autophagy 및 lysosome관련 유전자의 발현을 촉진 시키고, 세포질 내에 증가된 autosome과 lysosomal puncta의 관찰을 가능하게 하였다. Hinokitiol를 HCC827세포에 처리한 경우에서, 세포 내 autophagy의 증가와 더불어, mitochondria의 hyper-fragmentation과 mitochondria의 authophagic degradation (mitophagy)가 함께 증가되는 것이 관찰 되었다. Hinokitiol은 자궁경부암 세포주인 HeLa세포와 비소 세포 폐암 세포주인 HCC827에서 암세포 특이 독성을 나타내 었다. 더욱이, TFEB 과발현을 통해 autophagy를 인위적으로 증가시킨 HeLa 세포에서 hinokitiol에 대한 세포독성은 더욱 강화된 것으로 나타났다. 이러한 결과들을 통해, hinokitiol은 TFEB의 핵으로의 이동을 촉발시키는 강력한 autophagy inducer임을 확인할 수 있었다. 본 연구에서 처음으로 확인된 hinokitiol에 의한 TFEB의 활성화 및 비소세포성 암세포에서 항암효과의 상승작용은 다양한 항암제 저항성 세포들에 대한 새로운 치료법 및 대체요법 개발과 관련된 의미 있는 결과로 향 후, 분자수준의 작용기작에 대한 추가적인 연구가 수행되어야 할 것으로 사료된다.

\section{Acknowledgements: None \\ Conflict of interest: None}

Author's information (Position): Lee $\mathrm{TB}^{1,2}$, M.T.; Jun $\mathrm{JH}^{2,3,4}$, Professor.

\section{REFERENCES}

1. Wang WK, Lin ST, Chang WW, Liu LW, Li TY, Kuo CY, et al. Hinokitiol induces autophagy in murine breast and colorectal cancer cells. Environ Toxicol. 2016;31:77-84. https://doi.org/10.1002/tox.22023.

2. Saniewski M, Horbowicz M, Kanlayanarat S. The biological activities of troponoids and their use in agriculture a review. J Hortic Res. 2014;22:5-19. https://doi.org/10.2478/johr-2014- 0001.

3. Glick D, Barth S, Macleod KF. Autophagy: cellular and molecular mechanisms. J Pathol. 2010;221:3-12. https://doi.org/ 10.1002/path.2697.

4. Mizushima N, Komatsu M. Autophagy: renovation of cells and tissues. Cell. 2011;147:728-741. https://doi.org/10.1016/ j.cell.2011.10.026.

5. Mizushima N. Autophagy: process and function. Genes Dev. 2007:21:2861-2873.

6. Liang XH, Jackson S, Seaman M, Brown K, Kempkes B, Hishoosh $\mathrm{H}$, et al. Induction of autophagy and inhibition of tumorigenesis by beclin 1. Nature. 1999;402:672-676.

7. Gozuacik D, Kimchi A. Autophagy as a cell death and tumor suppressor mechanism. Oncogene. 2004;23:2891-2906.

8. Settembre C, Di Malta C, Polito VA, Garcia Arencibia M, Vetrini F, Erdin S, et al. TFEB links autophagy to lysosomal biogenesis. Science. 2011;332:1429-1433. https://doi.org/10.1126/science. 1204592.

9. Martini-Stoica H, Xu Y, Ballabio A, Zheng H. The autophagy-lysosomal pathway in neurodegeneration: a TFEB perspective. Trends Neurosci. 2016;39:221-234. https://doi.org/10.1016/ j.tins.2016.02.0002.

10. Zhang J, Wang J, Wu J, Lu Y, Jiang J, Wang L, et al. Curcumin targets the TFEB-lysosome pathway for induction of autophagy. Oncotarget. 2016;75659-75671. https://doi.org/10.18632/ oncotarget.12318.

11. Song JX, Sun YR, Peluso I, Zeng Y, Yu X, Lu JH, et al. A novel curcumin analog binds to and activates TFEB in vitro and in vivo independent of MTOR inhibition. Autophagy. 2016;12: 1372-1389. https://doi.org/10.1080/15548627.2016.1179404.

12. Jayakumar T, Liu CH, Wu GY, Lee TY, Manubolu M, Hsieh CY, at 
al. Hinokitiol inhibits migration of A549 lung cancer cells via suppression of MMPs and induction of antioxidant enzymes and apoptosis. Int J Mol Sci. 2018;19:E939. https://doi.org/ 10.3390/ijms19040939.

13. Ouyang WC, Liao YW, Chen PN, Lu KH, Yu CC, Hsieh PL. Hinokitiol suppresses cancer stemness and oncogenicity in glioma stem cells by Nrf2 regulation. Cancer Chemother Pharmacol. 2017;80:411-419. https://doi.org/10.1007/s00280- 017-3381-y.

14. Huang CH, Jayakumar T, Chang CC, Fong TH, Lu SH, Thomas PA, et al. Hinokitiol exerts anticancer activity through downregulation of MMPs 9/2 and enhancement of catalase and SOD enzymes: in vivo augmentation of lung histoarchitecture. Molecules. 2015;20:17720-17734. https://doi.org/10.3390/ molecules201017720.

15. Li LH, Wu P, Lee JY, Li PR, Hsieh WY, Ho CC, et al. Hinokitiol induces DNA damage and autophagy followed by cell cycle arrest and senescence in gefitinib-resistant lung adenocarcinoma cells. PLoS One. 2014;9:E104203. https://doi.org/10.1371/ journal.pone.0104203.

16. Ouyang L, Luo Y, Tian M, Zhang SY, Lu R, Wang JH, et al. Plant natural products: from traditional compounds to new emerging drugs in cancer therapy. Cell Prolif. 2014;47:506-515. https://doi.org/10.1111/cpr.12143.

17. Napolitano G, Ballabio A. TFEB at a glance. J Cell Sci. 2016;129:2475-2481. https://doi.org/10.1242/jcs.146365.

18. Tsao YT, Huang YF, Kuo CY, Lin YC, Chiang WC, Wang WK, et al. Hinokitiol inhibits melanogenesis via AKT/mTOR signaling in B16F10 mouse melanoma cells. Int J Mol Sci. 2016;17:248. https://doi.org/10.3390/ijms17020248.

19. Lee JH, Jeong JK, Park SY. AMPK activation mediated by hinokitiol inhibits adipogenic differentiation of mesenchymal stem cells through autophagy flux. Int J Endocrinol. 2018;2018: E2014192. https://doi.org/10.1155/2018/2014192.

20. Wilken R, Veena MS, Wang MB, Srivatsan ES. Curcumin: a review of anti-cancer properties and therapeutic activity in head and neck squamous cell carcinoma. Mol Cancer. 2011;10:E12. https://doi.org/10.1186/1476-4598-10-12.

21. Wu WK, Coffelt SB, Cho CH, Wang XJ, Lee CW, Chan FK, et al. The autophagic paradox in cancer therapy. Oncogene. 2012; 31:939-953. https://doi.org/10.1038/onc.2011.295.

22. Gozuacik D, Kimchi A. Autophagy as a cell death and tumor suppressor mechanism. Oncogene. 2004;23:2891-2906.

23. Green DR, Galluzzi L, Kroemer G. Mitochondria and the autophagy-inflammation-cell death axis in organismal aging. Science. 2011;333:1109-1112. https://doi.org/10.1126/science. 1201940

24. Gomes LC, Di Benedetto G, Scorrano L. During autophagy mitochondria elongate, are spared from degradation and sustain cell viability. Nat Cell Biol. 2011;13:589-598. https://doi.org/ 10.1038/ncb2220.

25. Tagaya M, Arasaki K. Regulation of mitochondrial dynamics and autophagy by the mitochondria-associated membrane. Adv Exp Med Biol. 2017;997:33-47. https://doi.org/10.1007/ 978-981-10-4567-7_3.

26. Palikaras K, Lionaki E, Tavernarakis N. Mechanisms of mitoph- agy in cellular homeostasis, physiology and pathology. Nat Cell Biol. 2018;20:1013-1022. https://doi.org/10.1038/s41556-0180176-2.

27. Gkikas I, Palikaras K, Tavernarakis N. The role of mitophagy in innate immunity. Front Immunol. 2018;9:E1283. https://doi.org/10.3389/fimmu.2018.01283.

28. Wilfinger N, Austin S, Scheiber-Mojdekhar B, Berger W, Reipert $\mathrm{S}$, Praschberger $\mathrm{M}$, at al. Novel p53-dependent anticancer strategy by targeting iron signaling and BNIP3L-induced mitophagy. Oncotarget. 2016;7:1242-1261. https://doi.org/ 10.18632/oncotarget.6233.

29. Lipinski MM, Zheng B, Lu T, Yan ZY, Py BF, Ng A, et al. Genome-wide analysis reveals mechanisms modulating autophagy in normal brain aging and in Alzheimer's disease. Proc Natl Acad Sci USA. 2010;107:14164-14169. https://doi.org/10.1073/pnas.1009485107.

30. Madeo F, Tavernarakis N, Kroemer G. Can autophagy promote longevity? Nat Cell Biol. 2010;12:842-846. https://doi.org/10.1038/ncb0910-842.

31. Kim W, Kim M, Jho EH. Wnt/beta-catenin signalling: from plasma membrane to nucleus. Biochem J. 2013;450:9-21. https://doi.org/10.1042/BJ20121284.

32. Clevers H, Nusse R. Wnt/beta-catenin signaling and disease. Cell. 2012;149:1192-1205. https://doi.org/10.1016/j.cell.2012. 05.012 .

33. MacDonald BT, Tamai K, He X. Wnt/beta-catenin signaling: components, mechanisms, and diseases. Dev Cell. 2009;17: 9-26. https://doi.org/10.1016/j.devcel.2009.06.016.

34. Yoshida T, Sopko NA, Kates M, Liu X, Joice G, McConkey DJ, et al. Three dimensional organoid culture reveals involvement of Wnt b catenin pathway in proliferation of bladder cancer cells. Oncotarget. 2018;9:11060-11070. https://doi.org/10.18632/ oncotarget.24308.

35. Rayan A, Raiyn J, Falah M. Nature is the best source of anticancer drugs: Indexing natural products for their anticancer bioactivity. Plos One. 2017;12:E0187925. https://doi.org/ 10.1371/journal.pone.0187925.

36. Thorburn A, Thamm DH, Gustafson DL. Autophagy and cancer therapy. Mol Pharmacol. 2014;85:830-838. https://doi.org/ 10.1124/mol.114.091850.

37. Lee TB, Seo EJ, Lee JY, Jun JH. Synergistic anticancer effects of curcumin and hinokitiol on gefitinib resistant non-small cell lung cancer cells. Nat Prod Commun. 2018;13:1667-1671. https://doi.org/10.1177/1934578X1801301223.

38. Ouyang L, Shi Z, Zhao S, Wang FT, Zhou TT, Liu B, et al. Programmed cell death pathways in cancer: a review of apoptosis, autophagy and programmed necrosis. Cell Prolif. 2012; 45:487-498. https://doi.org/10.1111/j.1365-2184.2012.00845.x.

39. Gao C, Cao WP, Bao L, Zuo W, Xie G, Cai T, et al. Autophagy negatively regulates Wnt signalling by promoting Dishevelled degradation. Nat Cell Biol. 2010;12:781-790. https://doi.org/10.1038/ncb2082.

40. Zhan T, Rindtorff N, Boutros M. Wnt signaling in cancer. Oncogene. 2017;36:1461-1473. https://doi.org/10.1038/onc. 2016.304. 